\title{
EL DERECHO DE ACCESO A LA JUSTICIA FRENTE A LA PANDEMIA COVID- 19 EN MÉXICO
}

\section{THE RIGHT OF ACCESS TO JUSTICE AGAINST THE COVID-19 PANDEMIC IN MEXICO}

Raul Montoya Zamora ${ }^{1}$

\section{RESUMEN}

El objetivo de este trabajo consiste en analizar la constitucionalidad y convencionalidad (conformidad con los tratados internacionales en materia de derechos humanos) de decretar el cierre de servicios de acceso a la justicia en México, por causa o con motivo de la pandemia COVID-19.

Por lo que, con apoyo en el método dogmático jurídico, exegético, y análisis de caso, en primer término, se desarrollará una base teórica y jurisprudencial sobre los alcances del Derecho Humano de acceso a la justicia; luego se analizarán las bases constitucionales y legales vigentes en México aplicables a la pandemia COVID-19, y finalmente, se dará respuesta al planteamiento central.

Palabras clave: Derechos humanos; acceso a la justicia; derecho a la salud; pandemia COVID19.

\begin{abstract}
The objective of this work is to analyse the constitutionality and conventionality (conformity with international treaties on human rights) of decreeing the closure of services of access to justice in Mexico, for cause or on the occasion of the PANdemic COVID-19.

So with support in the legal, exegenetic, comparative, and case-based dogmatic method, a theoretical and jurisprudential basis will be developed on the scope of the Human Right of Access to Justice; the constitutional and legal bases in force in Mexico applicable to the COVID-19 pandemic will then be analysed, and finally, the central approach will be answered.
\end{abstract}

Keywords: Human rights; access to justice; right to health; COVID-19 pandemic.

\footnotetext{
${ }^{1}$ doctor en derecho por la universidad juárez del estado de durango. Especialista en justicia constitucional por la universidad de castilla-la mancha. Profesor-investigador del instituto de investigaciones jurídicas de la universidad juárez del estado de durango. Universidad Juárez del Estado de Durango-Instituto de Investigaciones Jurídicas - $\quad$ México. ORCID: https://orcid.org/0000-0002-9886-6376 Lattes: http://lattes.cnpq.br/6875091942412127 E-mail: paranhos.denise@uol.com.br
} 


\section{PLANTEAMIENTO INTRODUCTORIO}

Como antecedente inmediato de una pandemia previa al COVID-19, se puede citar la ocurrida en el año del 2009, con la H1N1, la cual fue detectada en Estados Unidos, y después, se propagó en el resto del Mundo. Sobre el particular, se destaca que, en México, con motivo de dicha pandemia, no se decretó el cierre ni se suspendió el derecho de acceso a la justicia (Centro para el Control y la Prevención de Enfermedades, 2020, y Reynoso, 2010).

El COVID-19 tuvo su origen a mediados del mes de diciembre del 2019 en la ciudad de Wuhan, China, donde empezaron a darse una serie de neumonías de origen desconocido, lo que originó la alarma sobre una nueva enfermedad que muy pronto se dispersaría alrededor del planeta, causando miles de infectados y muertos hasta el momento (Redacción Médica, 2020).

El día 11 de marzo de 2020, el director general de la Organización Mundial de la Salud (OMS), en la rueda de prensa sobre el COVID19, dio a conocer que se estaba frente a una pandemia originada por un coronavirus nunca antes vista, por lo que invitó a todas las naciones del mundo a cerrar filas en contra de esta nueva amenaza mundial, a fin de evitar el crecimiento en la propagación del número de casos, pero sobre todo, de pérdida de vidas humanas. De igual modo, el director de la OMS hizo un llamamiento a los países a informar a sus pueblos sobre los riesgos existentes y la forma de protegerse; para encontrar, aislar, someter a prueba y tratamiento todos los casos, y rastrear a sus contactos; preparar a sus hospitales y formar y proteger a su personal sanitario, y lo más importante, a cuidarnos los unos de los otros porque nos necesitamos (Organización Mundial de la Salud, 2020).

En México existe un marco Constitucional y legal que debe de observarse de una manera adecuada para hacer frente a la pandemia del COVID-19, por lo que se formulan las siguientes preguntas claves que guiarán el presente texto.

¿Cuál es el régimen constitucional y legal aplicable cuando se presente un problema sanitario como el del COVID-19 en México? ¿La autoridad sanitaria competente puede restringir o limitar los derechos? ¿Cuál es el alcance del derecho de acceso a la justicia? ¿Se puede restringir o suspender el derecho de acceso a la justicia con motivo de la pandemia COVID-19? ¿Es conforme a la Constitución y a los tratados internacionales en materia de derechos humanos restringir el derecho de acceso a la justicia a causa de la pandemia en cuestión?

Situación que nos parece de la mayor importancia, debido a que a la fecha en que esto se escribe, tanto el Poder Judicial de la Federación, como casi la totalidad de los poderes judiciales de los Estados, y tribunales administrativos y del trabajo, han emitido acuerdos 
mediante los que se suspenden los plazos y términos procesales, a excepción de los asuntos considerados urgentes en términos de ley y de los acuerdos generales dictados por los órganos competentes, dejando prácticamente paralizada la actividad jurisdiccional en todo el país. Esto es, en el caso, existe en nuestro país una virtual suspensión del derecho de acceso a la justicia con motivo de la pandemia, en virtud de que el acceso a la justicia quedó limitado a los casos que la autoridad judicial considere como de urgente resolución en términos de ley, según se explicará más adelante (SCJN, 1, 2, 2020 Y CJF 1,2, 2020).

De ahí que el objetivo general del presente texto, consista en demostrar que resulta contrario a la Constitución y a los tratados internacionales en materia de Derechos Humanos, restringir o suspender el derecho humano de acceso a la justicia con motivo de la pandemia COVID-19.

En la elaboración del presente trabajo, se hará uso del método dogmático jurídico y exegético, porque se atienden a principios doctrinales y al sentido de las expresiones utilizadas en las normas jurídicas, para interpretar las normas relativas al marco constitucional y legal aplicable a las situaciones de emergencia derivadas de una epidemia. Además, el método de análisis de caso, se justifica, en virtud de que el estudio de fallos y precedentes relacionados con el derecho de acceso a la justicia, sobre todo, los emitidos por la Corte Interamericana de Derechos Humanos, permitirán destacar los alcances de este derecho, y su importancia en el contexto de una emergencia sanitaria, como un derecho que no puede ser objeto de restricción o suspensión.

En ese sentido, para el desarrollo del presente trabajo, en primer término, se aborda lo relativo al derecho humano de acceso a la justicia, por ser prioritario establecer los alcances e importancia de ese derecho humano, en la lógica del objetivo principal que se pretende alcanzar. Luego, en otro apartado se analiza el marco constitucional y legal aplicable a la pandemia COVID-19, con el propósito principal de establecer si conforme a ese marco, se puede desprender alguna especie de autorización para restringir o suspender el derecho de acceso a la justicia. Y finalmente, en un tercer apartado, se aborda la problemática principal que guía el texto, que consiste en demostrar que resulta contrario a la Constitución y a los tratados internacionales en materia de derechos humanos decretar el cierre de servicios de acceso a la justicia, esto es, dicho en otros términos, que resulta inconstitucional e inconvencional restringir o suspender el derecho de acceso a la justicia con motivo del COVID-19.

\section{EL DERECHO HUMANO DE ACCESO A LA JUSTICIA}


El artículo 17 de la Constitución Política de los Estados Unidos Mexicanos (CPEUM), consagra el derecho humano de acceso a la justicia, al señalar que: "toda persona tiene derecho a que se le administre justicia por tribunales que estarán expeditos para impartirla en los plazos y términos que fijen las leyes, emitiendo sus resoluciones de manera pronta, completa e imparcial. Su servicio será gratuito, quedando, en consecuencia, prohibidas las costas judiciales".

El derecho humano de acceso a la justicia, también tiene su fundamento en diversos instrumentos internacionales en materia de derechos humanos, tales como el artículo 10 de la Declaración Universal de los Derechos Humanos; 8 y 25 de la Convención Americana Sobre Derechos Humanos (reconocido como garantías judiciales y derecho a la protección judicial por esa convención), y 14 del Pacto Internacional de Derechos Civiles y Políticos (garantías judiciales).

El derecho de acceso a la justicia, consiste: "en la potestad y capacidad que tiene toda persona para acudir ante la autoridad judicial competente demandando que se preserve o se reestablezca una situación jurídica perturbada que lesiona o desconoce sus derechos o intereses legítimos" (Real Academia Española, 2020).

De acuerdo con el Diccionario de Español Jurídico en cita, el derecho a la tutela judicial efectiva (nombre con el cual también se refiere al derecho de acceso a la justicia en España), tiene, como contenido esencial, el de obtener de los órganos integrantes del poder judicial, una resolución razonada y fundada en derecho sobre el fondo de los planteamientos oportunamente hechos valer por las partes en un juicio, y al tratarse de un derecho de configuración legal, su ejercicio y dispensación están sujetos a la concurrencia de los presupuestos y requisitos que haya establecido el legislador para cada sector del ordenamiento procesal (Real Academia Española, 2020).

Este derecho fundamental, enmarca la facultad de las personas de acudir a los órganos jurisdiccionales para obtener de ellos una reparación de sus derechos, en caso de violación, con la finalidad de no quedar indefensos. Por lo que el derecho de acceso a la justicia se puede calificar como un derecho fundamental de prestación (Pérez, 2020).

Una noción amplía del derecho de acceso a la justicia, hace referencia a la potestad de ofrecer a todas las personas por igual, la posibilidad para acceder al conocimiento, ejercicio, y defensa de sus derechos y obligaciones, a través de los servicios de impartición de justicia, la cual deberá ser pronta, expedita y ágil (Islas y Díaz, 2016, p. 50).

De acuerdo con lo anterior, el derecho fundamental de acceso a la justicia, es un derecho establecido tanto en la Constitución Federal como en los tratados internacionales en materia de 
derechos humanos, que faculta a todas las personas para acudir a los órganos jurisdiccionales con la finalidad de reclamar ante éstos la violación de sus derechos, y así obtener el dictado de una sentencia que repare la violación reclamada.

Este derecho garantiza que todas las personas, sin distinción de raza, orientación sexual, identidad de género, condición socio económica, preferencia política, creencia religiosa, o cualquier otra categoría sospechosa discriminatoria de las prohibidas por el artículo $1^{\circ}$ de la CPEUM; puedan acudir a los tribunales para que se le reconozcan y protejan sus derechos. Por lo que el acceso a la justicia debe garantizar la igualdad de condiciones para que todas las personas puedan hacer uso de los instrumentos y mecanismos de defensa legales que existen para la protección de sus derechos.

En la jurisprudencia nacional, la primera Sala de la Suprema Corte de Justicia de la Nación (SCJN), ha dotado de contenido al derecho de acceso a la justicia, señalando que comprende, en adición a determinados factores socioeconómicos y políticos, el derecho a una tutela jurisdiccional efectiva y los mecanismos de tutela no jurisdiccional, que también deben ser efectivos y estar fundamentados constitucional y legalmente (SCJN, 2017, 151).

Respecto del acceso a la tutela judicial efectiva, la SCJN lo definió como el derecho público subjetivo que tiene toda persona para acceder, dentro de los plazos fijados en las leyes, de manera expedita, a tribunales independientes e imparciales, a plantear una pretensión o a defenderse de ella, con el fin de que a través de un proceso en el que se respeten las formalidades esenciales, se decida sobre la pretensión o defensa, y en su caso, se ejecute tal decisión (SCJN, $2017,151)$.

Por lo que este derecho, consta de tres etapas, a los que les corresponden 3 derechos: a) una previa de juicio, al que le corresponde el derecho de acceso a la jurisdicción, que parte del derecho de acción como especie del derecho de petición, dirigido a las autoridades jurisdiccionales y que motiva una respuesta de su parte; b) una etapa judicial, que comprende desde el inicio del procedimiento hasta la última actuación, a la que le pertenece el derecho al debido proceso legal; c) una etapa posterior al juicio, identificada con el derecho a la eficacia de las resoluciones emitidas. Tales derechos son oponibles no sólo a los órganos del Poder Judicial, sino a todos los órganos que realicen funciones materialmente jurisdiccionales (SCJN, 2017, 151).

En la jurisprudencia interamericana existen diversos criterios en torno al derecho a la protección judicial. Por ejemplo, en el caso Maritza Urrutia vs. Guatemala, la Corte Interamericana de Derechos Humanos (CORTIDH) argumentó que no es suficiente que los recursos existan formalmente, sino que los mismos deben de dar respuestas a violaciones a 
derechos humanos para que puedan estimarse efectivos. Es decir, el derecho que toda persona debe tener acceso a un recurso sencillo y rápido ante tribunales competentes que amparen sus derechos fundamentales, es una garantía que constituye uno de los pilares básicos no sólo de la Convención Americana, sino del propio Estado de Derecho en una sociedad democrática en el sentido de la Convención (CORTIDH, 2003, párrafo 117).

En el caso Jorge Castañeda Gutman vs. México, el tribunal interamericano razonó que la "efectividad del recurso" implica que el órgano judicial ha evaluado los méritos de la denuncia. Por lo que el análisis por la autoridad competente de un recurso judicial, no puede reducirse a una simple formalidad, sino que debe examinar las razones invocadas por el demandante y manifestarse expresamente sobre ellas, de conformidad con los parámetros establecidos en la convención. En otros términos, constituye una garantía mínima que toda persona que interpone un recurso, reciba una respuesta fundada y motivada, bajo pena de violar las garantías del debido proceso (CORTIDH, 2008, párrafo 93).

El mismo criterio es reiterado por la CORTIDH en el caso López Álvarez vs. Honduras (CORTIDH, 2006, párrafo 96).

Por lo que hace a la "accesibilidad del recurso", la CORTIDIH destacó la importancia de que los Estados regulen los recursos judiciales de forma tal, que las personas tengan certeza y seguridad jurídica de sus condiciones de acceso (CORTIDH, 2008, párrafo 110).

En el caso Cantos vs. Argentina, la CORTIDH argumentó que el artículo 8.1 de la Convención Americana consagra el derecho de acceso a la justicia, lo que implica que los Estados no deben interponer obstáculos a las personas que acudan a los jueces o tribunales en busca de que sus derechos sean determinados o protegidos. Por tanto, cualquier norma o medida de carácter interno de los Estados que imponga costos o dificulte de cualquier otra manera el acceso de las personas a los tribunales, y que no se encuentren justificadas por las razonables necesidades de la administración de justicia, debe considerarse contraria al artículo de la Convención citado. Por lo que para lograr una protección efectiva del derecho de acceso a la justicia, es preciso remover todo aquello que de manera razonable impida el objetivo de acceder a la justicia (CORTIDH, 2002, párrafo 50).

Del mismo modo, la resolución 1/2020 de la Comisión Interamericana de Derechos Humanos (CIDH), relativa al tema Pandemia COVID-19 y Derechos Humanos en las Américas, contiene un importante criterio en relación al derecho de acceso a la justicia, el cual, por su relevancia y pertinencia, abordaremos en el momento en el que se desarrolle el apartado en torno a la inconstitucionalidad e inconvencionalidad de restringir el derecho de acceso a la justicia en casos de pandemia. Aquí, basta señalar brevemente, que, para la CIDH, el derecho 
a la protección judicial no debe de restringirse ni suspenderse con motivo de la pandemia en cuestión (CIDH, 2020).

De todo lo anterior, se desprende la gran importancia que tiene el derecho humano de acceso a la justicia en una sociedad democrática, ya que es la piedra angular de todo Estado de Derecho, y sin su presencia, se tornarían en inefectivos todos los demás derechos y se propiciarían violaciones a los derechos humanos, sin que existiera la posibilidad de reclamar su reparación ante un tribunal independiente e imparcial.

\section{MARCO CONSTITUCIONAL Y LEGAL DEL RÉGIMEN DE SALUD PÚBLICA EN MÉXICO FRENTE A UNA EPIDEMIA O PANDEMIA}

Se inicia señalando que la salud es un derecho humano, y por ende un objetivo o finalidad constitucionalmente legítima que tiene el Estado mexicano, esto es, proteger y tutelar la salud de sus habitantes.

Así, el artículo $4^{\circ}$ de la Constitución Federal, nos indica que toda persona tiene derecho a la salud, dejando a la Ley la definición de las bases y modalidades para el acceso a los servicios de salud, estableciendo la concurrencia de la Federación y las entidades federativas en materia de salubridad general, conforme a lo que dispone la fracción XVI del artículo 73 de la misma Constitución (Cámara de Diputados del Congreso de la Unión 1, 2020).

De este primer acercamiento, se tiene que el derecho a la salud impone al Estado una obligación positiva, consistente en realizar todo en cuanto esté a su alcance para proteger ese derecho, y brindar los servicios necesarios para garantizarlo (médicos, hospitalarios, medicamentos, etcétera). Empero, también contiene una obligación de carácter negativo, de no hacer cosas que atenten contra ese derecho, como, por ejemplo, el Estado tiene la obligación de no contaminar el agua que se use para el consumo humano.

También se tiene que el acceso a los servicios de salud, participan concurrentemente la Federación y los Estados, en términos de lo previsto por el artículo 73, fracción XVI de la Constitución Federal. Esto significa que cada nivel de gobierno tiene sus propias competencias, las cuales son señaladas por la propia constitución y la Ley de la materia, esto es, la Ley General de Salud.

En la crisis sanitaria del COVID-19 por la que atraviesa nuestro país, el derecho a la salud impone una obligación positiva al Estado, esto es, tiene que actuar para hacer frente a esta crisis de salud. Pero también conlleva una vertiente negativa, es decir, no obstaculizar o entorpecer la protección de la salud de las personas. 
De igual manera, al ser el acceso a los servicios de salud una competencia concurrente, significa que tanto el Presidente como los Gobernadores tienen que hacer algo para afrontar el problema del COVID-19.

¿Pero qué es exactamente lo que le corresponde hacer a cada nivel de gobierno para hacer frente a esta pandemia?

\subsection{La Actuación del Consejo de Salubridad General y de la Secretaría de Salud en el Marco del COVID-19}

La fracción XVI del artículo 73 constitucional, contiene cuatro bases importantes sobre el tema.

La primera, es la existencia de un Consejo de Salubridad General (CSG), quien dependerá directamente del Presidente de la República, sin intervención de ninguna Secretaría de Estado, y sus disposiciones generales serán obligatorias en el país. La existencia de este Consejo data de 1917, es decir, desde la Constitución originaria se prevé la existencia de ese consejo (Cámara de Diputados del Congreso de la Unión 1, 2020).

La segunda, que en caso de epidemias de carácter grave (como la del COVID-19, que ya fue incluso declarada una pandemia) o peligro de invasión de enfermedades exóticas en el país, la Secretaría de Salud tendrá obligación de dictar inmediatamente las medidas preventivas indispensables, a reserva de ser después sancionadas por el Presidente de la República (Cámara de Diputados del Congreso de la Unión 1, 2020).

La tercera, es que la autoridad sanitaria será ejecutiva y sus disposiciones serán obedecidas por las autoridades administrativas del País (Cámara de Diputados del Congreso de la Unión 1, 2020).

Y finalmente, la cuarta, es que las medidas que el Consejo haya puesto en vigor en la Campaña contra el alcoholismo y la venta de sustancias que envenenan al individuo o degeneran la especie humana, así como las adoptadas para prevenir y combatir la contaminación ambiental, serán después revisadas por el Congreso de la Unión en los casos que le competan (Cámara de Diputados del Congreso de la Unión 1, 2020).

Conforme al artículo 15 de la Ley General de Salud (LGS), el CSG es un órgano que depende directamente del Presidente de la República en los términos del artículo 73, fracción XVI, constitucional. Está integrado por un presidente que será el Secretario de Salud, un secretario y trece vocales titulares, dos de los cuáles serán los presidentes de la Academia Nacional de Medicina y de la Academia Mexicana de Cirugía, y los vocales que su propio reglamento determine. Los miembros del Consejo serán designados y removidos por el 
Presidente de la República, quien deberá nombrar para tales cargos, a profesionales especializados en cualquiera de las ramas sanitarias (Cámara de Diputados del Congreso de la Unión 2, 2020).

Las atribuciones del CSG se encuentran establecidas en el artículo 17 de la LGS (Cámara de Diputados del Congreso de la Unión 2, 2020). Otra normativa importante que regula el funcionamiento del CSG es el Reglamento Interior del CSG, en el que se establecen sus funciones, llamando especial atención, la prevista en la fracción XVII del artículo 9, que dispone le corresponde al citado Consejo, aprobar y publicar en el Diario Oficial de la Federación la declaratoria en los casos de enfermedades graves que sean causa de emergencia (como el COVID-19) o atenten contra la seguridad nacional, por iniciativa propia o a solicitud por escrito de instituciones nacionales especializadas en la enfermedad, que sean acreditadas por el Consejo, en la que se justifique la necesidad de atención prioritaria (CSG, 2009).

Cómo se ve, el CSG tiene cierta autonomía en su funcionamiento, y puede dictar determinaciones obligatorias para las autoridades de todos los niveles de gobierno. Tal y como aconteció con la sesión llevada a cabo por ese CSG el día 19 de marzo del 2020, por el que reconoció la epidemia de enfermedad por el virus SARS-CoV2 (COVID-19) en México, como una enfermedad grave de atención prioritaria, y se establecen las actividades de preparación y respuesta ante dicha epidemia (CSG 1, 2020). De igual modo, en el acuerdo de cuenta se resuelve que la Secretaría de Salud determinará todas las acciones que resulten necesarias para atender la enfermedad en cuestión.

Dicho acuerdo fue acompañado del diverso dictado por la Secretaría de Salud, con fecha 24 de marzo de 2020, por el que se establecen las medidas preventivas que se deberán implementar para la mitigación y control de los riesgos para la salud que implica la enfermedad por el virus SARSCoV2 (COVID-19). Haciendo notar que se dictó 13 días después de que la OMS declaró que dicha enfermedad se trataba de una pandemia (Secretaría de Salud 1, 2020).

De igual manera, con fecha 30 de marzo de 2020, el CSG emitió un acuerdo por el que se declara como emergencia sanitaria por causa de fuerza mayor, a la epidemia de enfermedad generada por el virus SARS-CoV2 (COVID-19). En el acuerdo también se resuelve que la Secretaría de Salud determinará todas las acciones que resulten necesarias para atender la emergencia en cuestión (CSG 2, 2020).

Tal determinación fue complementada por el acuerdo de la Secretaría de Salud de fecha 31 de marzo del 2020, por el que se establecen acciones extraordinarias para atender la emergencia sanitaria generada por el virus SARS-CoV2 COVID-19 (Secretaría de Salud 2, 2020). 
Sobre la actuación de la Secretaría de Salud, nuestra Constitución en su artículo 76, fracción XVI, dispone lo que le corresponde hacer en caso de epidemias o enfermedades exóticas, señalando al efecto que tiene la obligación de dictar las medidas preventivas indispensables, a reserva de que después sean sancionadas por el Presidente de la República. Esto es, nuestra Constitución asume que el órgano de mayor experiencia y competencia para hacer frente a una pandemia o crisis de salud pública es la Secretaría de Salud, a tal punto que le permite actuar ejecutivamente (rápido), sin necesidad de que el Presidente sancione sus medidas a priori. Dichas medidas serán sancionadas a posteriori, es decir, la Secretaría de Salud puede dictar medidas rápidas sin tener la autorización del Presidente, ésta la puede obtener de manera posterior al dictado de las mismas (Cámara de Diputados del Congreso de la Unión 1, 2020).

Sin embargo, como se aprecia de los acuerdos dictados por el CSG de 23 y 30 de marzo del presente año, en contraposición a la lógica Constitucional, se autorizó a la Secretaría de Salud para que determinará todas las acciones que resultaran necesarias para atender la emergencia en cuestión, cuando en la especie, no se requería dicha autorización del CSG, porque la misma ya viene dada desde la propia Constitución para que la Secretaría de Salud actuara de manera rápida y eficaz.

Por lo que los acuerdos dictados por la Secretaría de Salud con fechas 24 y 31 de marzo del 2020, para atender el problema sanitario generado por el virus SARS-CoV2 COVID-19, podía haberlos emitido sin necesidad de contar con la autorización del CSG, pues se recuerda, que en tratándose de epidemias y enfermedades exóticas, la Secretaría de Salud es la autoridad ejecutiva, y sus determinaciones son obligatorias para todas las autoridades administrativas en el país, incluso entonces, para las autoridades de los Estados y Municipios.

Asimismo, el artículo 147 de la LGS dispone que en los lugares del territorio nacional en que cualquier enfermedad transmisible adquiera características epidémicas graves, a juicio de la Secretaría de Salud, así como en los lugares colindantes expuestos a la propagación, las autoridades civiles, militares y los particulares estarán obligados a colaborar con las autoridades sanitarias en la lucha contra dicha enfermedad. Como se ve del anterior precepto, en los casos de epidemia, las autoridades civiles, militares y los particulares, están obligados a colaborar con la Secretaría de Salud, en el entendido de que es la autoridad competente para dictar las medidas requeridas para hacer frente a la epidemia (Cámara de Diputados del Congreso de la Unión 2, 2020).

También el artículo 148 de la LGS, faculta a las autoridades sanitarias competentes (Secretaría de Salud) para utilizar como elementos auxiliares en la lucha contra las epidemias, 
todos los recursos médicos y de asistencia social de los sectores público, social y privado existentes en las regiones afectadas y en las colindantes, de acuerdo con las disposiciones de esta Ley y los reglamentos aplicables (Cámara de Diputados del Congreso de la Unión 2, 2020).

La Secretaría de Salud cuenta con la de facultad autorizar y permitir la internación en el territorio nacional de personas que padezcan enfermedades infecciosas en periodo de transmisibilidad que sean portadoras de agentes infecciosos o se sospeche que estén en periodo de incubación por provenir de lugares infectados (como el COVID-19), (Cámara de Diputados del Congreso de la Unión 2, 2020).

Incluso, para afrontar una epidemia, el artículo 152 de la LGS estipula que las autoridades sanitarias (léase competentes, en el caso, la Secretaría de Salud, y de manera extensiva el CSG) podrán ordenar, por causas de epidemia, la clausura temporal de los locales o centros de reunión de cualquier índole (Cámara de Diputados del Congreso de la Unión 2, 2020).

De igual forma, el artículo 359 de la LGS, determina que la Secretaría de Salud notificará a la (OMS) de todas las medidas que haya adoptado, de modo temporal o permanente, en materia de sanidad internacional. Asimismo, informará a esta misma organización y con la oportunidad debida, sobre cualquier caso que sea de interés en la vigilancia epidemiológica de las enfermedades que se citan en el Reglamento Sanitario Internacional, las que puedan originar epidemias (como la del COVID-19) o cualesquiera otras que considere de importancia notificar (Cámara de Diputados del Congreso de la Unión 2, 2020).

Tal y como se puede apreciar, la organización competencial resulta algo compleja, y esto se puede entender porque la protección a la salud implica la participación de varios niveles de gobierno, donde cada uno de ellos tienen su respectivo marco legal (véase Anexo 1).

Ahora bien ¿Qué le corresponde realizar a las entidades federativas y municipios en una crisis de salud pública como la que atravesamos? ¿Pueden dictar medidas adicionales o qué rebasen las adoptadas por el CSG o la Secretaría de Salud? ¿Pueden dichas autoridades dictar medidas que restrinjan o suspendan los derechos?

Del marco constitucional y legal referido, se aprecia que no se otorga competencia expresa alguna a los gobiernos de las entidades federativas y Municipios para dictar las medidas necesarias para hacer frente a una epidemia como el COVID-19.

Dicha situación es entendible desde el punto de vista constitucional, porque resulta más funcional y ejecutivo que la autoridad que determina la propia Carta Magna como la de mayor experiencia para hacer frente a una epidemia, dicte de manera rápida, incluso, sin tener la autorización del presidente, todas aquellas determinaciones necesarias para hacer frente a la 
pandemia. Con lo que se evita también el dictado de medidas dispersas, difusas, inconexas y restrictivas de derechos de los gobiernos estatales y municipales, que por mucho que puedan actuar de buena fe, no cuentan con la competencia para dictar medida alguna en estos casos.

Por tanto, la actuación de los gobiernos estatales y municipales ante la crisis de salubridad pública por la que se atraviesa, consistiría en ejecutar y cumplir con los acuerdos emanados del CSG y de la Secretaría de Salud, pues resultan vinculantes y obligatorios para todas las autoridades del país. Y Claro está, de manera implícita, también la de proporcionar los servicios salud necesarios para atender la epidemia en cuestión.

En ese orden de exposición, conforme a lo que hasta aquí hemos analizado, sólo la autoridad sanitaria federal, ya sea el CSG o la Secretaría de Salud, pero especialmente ésta última, son los únicos facultados para dictar todas aquellas medidas necesarias para afrontar la crisis epidemiológica relacionada con el COVID-19, por lo que las dictadas por las autoridades estatales y municipales, no tienen basamento constitucional alguno.

Sin embargo, el elenco de mecanismos constitucionales para hacer frente a una pandemia no se agota sólo en los que se han detallado, también existe la suspensión de derechos prevista en el artículo 29 constitucional, medida que desde nuestra modesta opinión, debe ser utilizada como última alternativa a recurrir, siempre y cuando se haya procurado controlar la emergencia sanitaria a través de otras medidas menos lesivas de derechos, pero idóneas y necesarias para proteger la salud pública de cara a este nuevo virus COVID-19.

A continuación, se da cuenta de este mecanismo constitucional.

\subsection{La Restricción y Suspensión de Derechos como Mecanismo para Afrontar el COVID-19 en México}

La restricción y suspensión de derechos, es un procedimiento constitucional en el que intervienen los tres poderes de la unión. El Ejecutivo quien emite el decreto de restricción y suspensión de derechos; el legislativo que lo aprueba y autoriza al ejecutivo la adopción de medidas necesarias para hacer frente a la situación extraordinaria, y el judicial, a través de la Suprema Corte de Justicia de la Nación, que revisa oficiosamente la constitucionalidad y validez del decreto en cuestión con la mayor prontitud posible.

Del texto del artículo 29 constitucional, se aprecia que la restricción y suspensión de derechos procede en los casos de invasión, perturbación grave de la paz pública, o de cualquier otro que ponga a la sociedad en grave peligro o conflicto (como puede ser la emergencia sanitaria originada por una epidemia como la del COVID-19), (Cámara de Diputados del Congreso de la Unión 1, 2020). 
En tal supuesto, el Presidente de la República con la aprobación del Congreso o de la Comisión Permanente, podrá restringir o suspender en todo el país o en un lugar determinado, el ejercicio de los derechos que fuesen obstáculo para hacer frente, rápida y fácilmente a la situación; pero deberá hacerlo por un tiempo limitado (no debe ser indeterminado, es decir, se debe señalar la temporalidad del decreto), por medio de prevenciones generales y sin que la restricción o suspensión se contraiga a determinada persona. Si la restricción o suspensión tuviese lugar hallándose el Congreso reunido, éste concederá las autorizaciones que estime necesarias para que el Ejecutivo haga frente a la situación; pero si se verificase en tiempo de receso, se convocará de inmediato al Congreso para que las acuerde (Cámara de Diputados del Congreso de la Unión 1, 2020).

En la emisión del decreto de restricción y suspensión, no podrá restringirse ni suspenderse el ejercicio de los derechos a la no discriminación, al reconocimiento de la personalidad jurídica, a la vida, a la integridad personal, a la protección a la familia, al nombre, a la nacionalidad; los derechos de la niñez; los derechos políticos; las libertades de pensamiento, conciencia y de profesar creencia religiosa alguna; el principio de legalidad y retroactividad; la prohibición de la pena de muerte; la prohibición de la esclavitud y la servidumbre; la prohibición de la desaparición forzada y la tortura; ni las garantías judiciales indispensables para la protección de tales derechos. Esto significa que esos derechos no pueden restringirse ni suspenderse bajo ninguna condición (Cámara de Diputados del Congreso de la Unión 1, 2020).

Adicionalmente, la restricción o suspensión del ejercicio de los derechos y garantías debe estar fundada y motivada en los términos establecidos por la Constitución y ser proporcional al peligro a que se hace frente, observando en todo momento los principios de legalidad, racionalidad, proclamación, publicidad y no discriminación (Cámara de Diputados del Congreso de la Unión 1, 2020).

Esta exigencia significa que el decreto en cuestión debe estar lo suficientemente argumentado, con premisas jurídicas y fácticas, en donde se considere además la idoneidad, necesidad y proporcionalidad en sentido estricto de la medida (ello en atención a la proporcionalidad que señala la norma constitucional), en correlación al peligro que se afronta. Debiendo de cumplir dicha medida los principios de legalidad (soportada en la ley), racionalidad (bajo este principio no cualquier restricción o suspensión cabe, sino solo aquella que sea racional para hacer frente a la situación de peligro), proclamación (que implica que la suspensión sea aprobada y dada a conocer por quien sea competente para tomarla) y no discriminación (Cámara de Diputados del Congreso de la Unión 1, 2020). 
La restricción o suspensión del ejercicio de los derechos y garantías, puede concluir de dos maneras: bien sea por cumplirse el plazo o porque así lo decrete el Congreso. En tales supuestos, todas las medidas legales y administrativas adoptadas durante su vigencia quedarán sin efecto de forma inmediata. Y el Ejecutivo no podrá hacer observaciones al decreto mediante el cual el Congreso revoque la restricción o suspensión (Cámara de Diputados del Congreso de la Unión 1, 2020).

Finalmente, como garantía de que el decreto emitido por el ejecutivo con aprobación del Congreso de la Unión sea apegado a la Constitución, la Suprema Corte de Justicia de la Nación, tiene la atribución de revisar su constitucionalidad y validez de manera oficiosa, lo cual deberá hacerlo con la mayor prontitud posible (Cámara de Diputados del Congreso de la Unión $1,2020)$

En suma, se considera que la restricción y suspensión de derechos y libertades prevista en el artículo 29 constitucional, debe ser utilizada como último recurso para hacer frente a la emergencia de salud ocasionada por el virus COVID-19, esto después de haber procurado contener la emergencia con otras medidas menos lesivas y restrictivas de Derechos.

\section{PARÁMETROS CONSTITUCIONALES Y CONVENCIONALES APLICABLES A LAS AUTORIDADES SANITARIAS COMPETENTES PARA HACER FRENTE A LA PANDEMIA COVID-19 EN MÉXICO}

El marco constitucional y legal de referencia, nos invita a reflexionar sobre los alcances que deben tener las medidas sanitarias dictadas por las autoridades competentes para contener la emergencia, es decir, cabe cuestionarse ¿El procedimiento previsto en el artículo 29 constitucional es el único por el cual se pueden restringir y/o suspender Derechos Humanos para hacer frente a la pandemia? ¿Las medidas administrativas que dicten las autoridades competentes para hacerse cargo de la emergencia sanitaria, pueden contener restricciones o suspender Derechos Humanos y sus garantías? ¿Hasta dónde pueden contener restricciones o suspender derechos las medidas implementadas por las autoridades sanitarias competentes? ¿Qué parámetros deben respetar las autoridades sanitarias competentes al momento de emitir acuerdos donde se restrinjan y/o suspendan derechos? ¿Es constitucional y convencional restringir o suspender el derecho de acceso a la justicia con motivo de la pandemia en cuestión? (véase anexo 2).

Sobre el particular, se considera que en principio, de una interpretación estricta de la normativa constitucional, el único procedimiento previsto para restringir y suspender derechos es el previsto en el artículo 29 constitucional, por ende, una primera conclusión sobre el tema, 
es que las medidas dictadas por las autoridades competentes para afrontar el problema epidemiológico del COVID-19, no debiesen tener restricciones y menos, suspender los Derechos Humanos.

Sin embargo, en los hechos, en el actuar cotidiano de la autoridad (sin que se suponga una emergencia como la que se está afrontando), se pueden constatar actos tanto administrativos como legislativos que contienen restricciones a los Derechos Humanos, y ello no conlleva a que necesariamente se tenga que seguir el procedimiento previsto en el artículo 29 constitucional.

Esto es entendible, porque las autoridades en su actuar tienen que atender cuestiones con la mayor prontitud posible que resuelvan los problemas que demanda la sociedad, y dentro de una sociedad democrática pluralista, la llevan a tomar determinaciones que tienden a proteger fines, valores y derechos constitucionalmente legítimos, pero que pueden limitar o restringir otros derechos de la misma jerarquía e importancia.

Precisamente es lo que está sucediendo con la actuación de la Secretaría de Salud para tratar de resolver la problemática derivada del COVID-19, donde sus acciones en lo fundamental están encaminadas a proteger el derecho humano a la salud de todos los habitantes de la república, lo cual constituye una finalidad constitucionalmente legitima y una obligación del Estado mexicano. Pero para cumplir con esa finalidad, la Secretaría de Salud ha tenido que dictar medidas de prevención, de contención, y aquellas tendentes a evitar la propagación del virus COVID-19, lo cual supone la restricción a otros derechos humanos de igual jerarquía que el derecho a la salud, tal y como se puede desprender de las facultades contenidas en los artículos 148, 152 y 359 de la LGS.

Así, por ejemplo, el acuerdo de la Secretaría de Salud por el que se establecen acciones extraordinarias para atender la emergencia sanitaria generada por el virus SARS-CoV2 COVID-19, contiene bastantes restricciones a otros derechos humanos, tales como el de la libertad de empresa, de comercio, de trabajo, de reunión, etcétera, tal y como se analiza a continuación (Secretaría de Salud 2, 2020).

En primer lugar, el acuerdo en cuestión ordenó a los sectores público, social y privado la suspensión inmediata, del 30 de marzo al 30 de abril de 2020, de las actividades no esenciales, con la finalidad de mitigar la dispersión y transmisión del virus SARS-CoV2 en la comunidad, para disminuir la carga de enfermedad, sus complicaciones y la muerte por COVID-19 en la población residente en el territorio nacional (Secretaría de Salud 2, 2020). 
Para tal efecto, se estimaron como actividades esenciales, entre otras, las siguientes: La procuración e impartición de justicia; así como la actividad legislativa en los niveles federal y estatal (Secretaría de Salud 2, 2020).

Asimismo, en el acuerdo en cuestión se dispuso que en todos los lugares y recintos en los que se realizan las actividades definidas como esenciales, se deberán observar, de manera obligatoria, las siguientes prácticas: a) No se podrán realizar reuniones o congregaciones de más de 50 personas; b) Las personas deberán lavarse las manos frecuentemente; c) Las personas deberán estornudar o toser aplicando la etiqueta respiratoria (cubriendo nariz y boca con un pañuelo desechable o con el antebrazo); d) No saludar de beso, de mano o abrazo (saludo a distancia), y e) Todas las demás medidas de sana distancia vigentes, emitidas por la Secretaría de Salud Federal (Secretaría de Salud 2, 2020).

El acuerdo también contiene un exhorto a toda la población residente en el territorio mexicano, incluida la que arribe al mismo procedente del extranjero y que no participa en actividades laborales esenciales, a cumplir resguardo domiciliario corresponsable del 30 de marzo al 30 de abril de 2020. Entendiendo por resguardo domiciliario corresponsable a la limitación voluntaria de movilidad, permaneciendo en el domicilio particular o sitio distinto al espacio público, el mayor tiempo posible (Secretaría de Salud 2, 2020).

Tal resguardo domiciliario corresponsable, debe aplicarse de manera estricta a toda persona mayor de 60 años de edad, estado de embarazo o puerperio inmediato, o con diagnóstico de hipertensión arterial, diabetes mellitus, enfermedad cardíaca o pulmonar crónicas, inmunosupresión (adquirida o provocada), insuficiencia renal o hepática, independientemente de si su actividad laboral se considera esencial. El personal esencial de interés público podrá, de manera voluntaria, presentarse a laborar (Secretaría de Salud 2, 2020).

De igual manera, se pospusieron, hasta nuevo aviso, todos los censos y encuestas a realizarse en el territorio nacional que involucren la movilización de personas y la interacción física (cara a cara) entre las mismas (Secretaría de Salud 2, 2020).

Todas las medidas anteriores, deben de aplicarse con estricto respeto a los derechos humanos de las personas (Secretaría de Salud 2, 2020).

Finalmente, se dispuso que una vez terminado el periodo de vigencia de las medidas establecidas en el citado acuerdo, la Secretaría de Salud, en coordinación con la Secretaría de Economía y la Secretaría del Trabajo y Previsión Social, emitirán los lineamientos para un regreso, ordenado, escalonado y regionalizado a las actividades laborales, económicas y sociales de toda la población en México (Secretaría de Salud 2, 2020). 
Como puede apreciarse del acuerdo en cuestión, en éste se contienen restricciones severas a derechos humanos, siendo los principales, los relacionados con la libertad de empresa, comercio y al trabajo, a través de la suspensión de actividades no esenciales, inferidas de la definición por denotación de las actividades esenciales.

El acuerdo en cuestión, también contiene una restricción leve (véase anexo 3) al derecho de libertad de circulación, a modo de un exhorto a toda la población residente en el territorio mexicano, incluida la que arribe al mismo procedente del extranjero y que no participa en actividades laborales esenciales, a cumplir con un resguardo domiciliario corresponsable del 30 de marzo al 30 de abril de 2020. Debiendo de aplicarse de manera estricta a toda persona mayor de 60 años de edad, estado de embarazo o puerperio inmediato, o con diagnóstico de hipertensión arterial, diabetes mellitus, enfermedad cardíaca o pulmonar crónicas, inmunosupresión (adquirida o provocada), insuficiencia renal o hepática, independientemente de si su actividad laboral se considera esencial.

Sobre el particular, cabe señalar que conforme al artículo 12, párrafo 3, del Pacto Internacional de Derechos Civiles y Políticos, se puede restringir la libertad de circulación cuando sea necesario para proteger la salud pública, y la restricción sea compatible con los demás derechos reconocidos en el pacto.

Ahora bien, sobre el debate de si una autoridad administrativa como la Secretaría de Salud, puede emitir un acuerdo que restrinja o suspenda derechos humanos para hacer frente a la epidemia del COVID-19 o se tiene que acudir al procedimiento del artículo 29 constitucional, se considera que la autoridad sanitaria en su acuerdo sí podría restringir ciertos derechos humanos que se estimen necesarios para superar la contingencia (no suspender) pero de una manera leve o moderada, es decir, no tan intensa, pero siempre haciendo una ponderación o balance de todos los derechos implicados, en aras de no interferir de manera grave o severa con cualquiera de ellos, a tal punto que lo lleve a su completo desconocimiento o vulnerar su contenido esencial (Alexy, 1997).

Esto es, en términos de la resolución 1/2020, resolutivo 20, de la Comisión Interamericana de Derechos Humanos (CIDH), las restricciones deben cumplir con el principio de legalidad, ser necesarias en una sociedad democrática y, por ende, resultar estrictamente proporcionales para atender la finalidad legítima de proteger la salud (CIDH, 2020).

Para ello, la autoridad sanitaria tendría que haber recurrido a un test de proporcionalidad tal y como lo define muy bien Alexy (1997, P. 147), (y que se encuentra expresamente establecido en el artículo 29 constitucional para el caso de restricción y suspensión de derechos), con el objeto de verificar que sus medidas que atienden a la protección de un fin 
constitucional legítimo, como lo es el derecho a la salud, fueran las idóneas, necesarias y proporcionales para lograr su cometido, atendiendo a cierta escala medible de restricción de los derechos, de tal suerte que sus medidas en aras de garantizar el derecho a la salud, no lesionen de manera grave o hagan nugatorios otros derechos que interfieren en el logro de la finalidad constitucional, como bien pudiera ser, por ejemplo, el derecho de acceso a la justicia.

Un ejemplo muy sencillo sobre cómo opera lo antes dicho, se tiene con la restricción impuesta por la autoridad sanitaria a la libertad de circulación, relativa al resguardo domiciliario corresponsable, que consiste en permanecer de manera voluntaria en el domicilio el mayor tiempo posible. Como se mencionó, la restricción a la libertad de circulación impuesta se estima de leve a moderada, porque no es un confinamiento de carácter obligatorio que lleve a una sanción en caso de incumplimiento.

Por lo que, si se hace una evaluación rápida de dicha medida, se tiene que en primer lugar atiende a un fin constitucional legítimo (la protección a la salud), dicha medida se estima idónea porque guarda relación medio-fin, es decir, es apta para conseguir el fin constitucional legítimo. En cuanto a la necesidad, que atiende a buscar que la medida tomada sea la que menos interfiera de modo intenso o grave con otros derechos, se cumple, ya que, al no ser un confinamiento obligatorio, las personas tienen la oportunidad de disfrutar de su derecho a la libre circulación sin que nadie las sancione si deciden salir de sus domicilios. Y finalmente, en cuanto a la proporcionalidad de la medida, en función a la idoneidad y necesidad de la misma, se concluye que es la que permite el cumplimiento del fin constitucional legítimo e interfiere en menor grado con el derecho a la libertad de circulación.

Consecuentemente, como se apuntó, la autoridad sanitaria competente sí tendría competencia para emitir medidas para contener el COVID-19 que contengan ciertas restricciones leves o moderadas a los derechos, como la analizada muy superficialmente, sin tener que acudir al procedimiento del artículo 29 constitucional.

Empero, cuando las medidas dictadas por la autoridad sanitaria restrinjan de modo grave o severo otros derechos humanos, a tal punto de afectar el contenido esencial del derecho, así sea para cumplir con un fin constitucional legítimo como lo es la protección a la salud, en nuestra modesta opinión se tendría que acudir al procedimiento de suspensión de derechos previsto por el artículo 29 constitucional, ya que éste viene reforzado de varias garantías a favor de las personas, que en principio impedirían se tomaran decisiones arbitrarias sobre los derechos, según se analizó en su oportunidad (por ejemplo el artículo 29 constitucional señala los derechos humanos que no se pueden suspender bajo ninguna condición, un control parlamentario por parte del poder legislativo, la obligación de motivar las restricciones en 
función a la proporcionalidad de las medidas tomadas, la revisión oficiosa que debe efectuar la SCJN sobre el decreto de restricción o suspensión de derechos, entre otras).

Sobre el particular, y con la finalidad de que esto contribuya al debate y reflexión sobre el tema, en nuestra opinión, el acuerdo dictado por la Secretaría de Salud que se analiza, contiene una serie de restricciones graves o severas a los derechos de libre empresa, comercio y empleo, que se materializaron con la suspensión de actividades consideradas como no esenciales, a partir de la definición por denotación de aquellas que se consideraron esenciales.

Lo anterior, porque en principio, no se aprecia el criterio bajo el cual se definieron las actividades esenciales, lo cual dejó a muchas otras empresas, comercios y personas sin posibilidad de seguir desarrollando su actividad. Y, además, no se puede percibir que la restricción para las actividades consideradas como no esenciales sea una medida idónea, necesaria y proporcional para conseguir el fin constitucional legítimo, y sí contiene una restricción severa a los derechos de libertad de empresa, comercio y empleo, porque contiene una prohibición absoluta para aquellas actividades no esenciales.

En vista de lo anterior, se considera que el acuerdo en cuestión emitido por la Secretaría de Salud, en mayor parte se trata de un acuerdo de restricción severa de derechos humanos, por lo que se tenía que haber acudido al procedimiento previsto en el artículo 29 constitucional.

Incluso, en vísperas hacia la transición a la fase 3 de la emergencia sanitaria, donde la experiencia en otros países (como España y Francia) sugiere una restricción más severa al derecho de libre circulación, se considera que la Secretaría de Salud (mucho menos las autoridades estatales y municipales) no tendría atribuciones para decretar un toque de queda o limitaciones más severas a la libertad de circulación, por lo que necesariamente tendría que acudirse al procedimiento previsto en el 29 de nuestra carta fundamental.

De lo anterior se puede destacar la necesidad de un marco regulatorio más claro en materia de restricción y suspensión de derechos en los casos de una emergencia sanitaria como la que estamos atravesando, con la finalidad de dejar claro a las autoridades administrativas competentes (CSG y Secretaría de Salud Federal), los derechos que puede limitar, los que no pueden limitar, su grado de afectación y limitación, la temporalidad de la limitación, y la posibilidad de un control parlamentario o judicial a posteriori. Ello con el objetivo de garantizar que las medidas dictadas por las autoridades competentes sean las idóneas, necesarias, proporcionales y sean lo menos invasivas con otros derechos humanos de igual importancia que el derecho a la salud y a la vida. 


\section{SOBRE LA INCONSTITUCIONALIDAD E INCONVENCIONALIDAD DE RESTRINGIR O SUSPENDER EL ACCESO A LA JUSTICIA: CONCLUSIÓN Y PROPUESTA}

Previo a fijar nuestra postura en torno a la problemática principal, en el desarrollo del presente trabajo se destacó que el derecho humano de acceso a la justicia es de gran importancia en una sociedad democrática, ya que es la piedra angular de todo Estado de Derecho, y sin su presencia, se tornarían en inefectivos todos los demás derechos y se propiciarían violaciones a los derechos humanos, sin que existiera la posibilidad de reclamar su reparación ante un tribunal independiente e imparcial.

Igualmente, conforme al marco constitucional y legal vigente aplicable al COVID-19 en México, solo la Secretaría de Salud Federal y el Consejo de Salubridad General, tienen competencias para dictar las medidas sanitarias para hacer frente a la emergencia. Por lo que la Constitución ni las leyes, otorgan facultades a los Estados y Municipios en la materia.

$\mathrm{Y}$ esto es particularmente relevante, porque no han faltado autoridades estatales y municipales que ya dictaron sus correspondientes medidas sanitarias, siendo algunas de ellas, verdaderos catálogos de restricciones de derechos humanos, que rebasan por mucho las determinaciones dictadas por el momento por la autoridad sanitaria competente.

Un ejemplo de lo anterior, lo constituye el decreto de fecha 25 de marzo de 2020, expedido por el Gobierno del Estado de Sonora, mediante el cual se emitió la declaratoria de emergencia y contingencia sanitaria epidemiológica y por el que se dictan las medidas urgentes encaminadas al mejoramiento de la Salubridad pública general en el Estado de Sonora, en donde se ordenan diversas acciones para prevenir, controlar, combatir y erradicar la existencia y transmisión del COVID-19. En dicho acuerdo, se contienen medidas que en el momento en el que fueron dictadas, fueron más allá de lo dispuesto hasta el momento por las autoridades sanitarias competentes. En ese sentido se dispuso la suspensión de actividades no esenciales, se ordenó el cierre de bares, centros, casinos, espectáculos deportivos, entre otras medidas restrictivas de derechos, que por muy buena intención con que fuese emitido el decreto en cuestión, resulta inconstitucional porque no proviene de una autoridad competente para dictarlo (Gobierno del Estado de Sonora, 2020).

Asimismo, se estableció que la autoridad sanitaria competente sí tendría competencia para emitir medidas para contener el COVID-19 que contengan ciertas restricciones leves o moderadas a los derechos, como las que se analizaron, sin tener que acudir al procedimiento del artículo 29 constitucional, pero dichas determinaciones tendrían que perseguir un fin 
constitucional legítimo, ser idóneas, necesarias y proporcionales (en sentido estricto), de tal suerte que interfiera lo menos posible con otros derechos fundamentales de igual jerarquía y relevancia.

Sin embargo, también se concluyó que cuando las medidas dictadas por la autoridad sanitaria restrinjan de modo grave o severo otros derechos humanos, a tal punto de afectar el contenido esencial del derecho, así sea para cumplir con un fin constitucional legítimo como lo es la protección a la salud, en nuestra modesta opinión; tendría que acudir al procedimiento de suspensión de derechos previsto por el artículo 29 constitucional, ya que éste viene reforzado de varias garantías a favor de las personas, que en principio impedirían se tomaran decisiones arbitrarias sobre los derechos, según se analizó en su oportunidad.

De igual modo, se precisaron los elementos para abrir la discusión en el futuro, sobre la necesidad de un marco regulatorio más claro en materia de restricción y suspensión de derechos en los casos de una emergencia sanitaria como la que estamos atravesando, con la finalidad de dejar claro a las autoridades administrativas competentes (CSG y Secretaría de Salud Federal), los derechos que puede limitar, los que no pueden limitar, su grado de afectación y limitación, la temporalidad de la limitación, y la posibilidad de un control parlamentario o judicial a posteriori. Lo anterior, con el propósito de garantizar que las medidas dictadas por las autoridades competentes sean las idóneas, necesarias, proporcionales y sean lo menos invasivas con otros derechos humanos de igual importancia que el derecho a la salud y a la vida.

En lo que concierne al tema central de nuestro trabajo, referido a la restricción y suspensión del derecho de acceso a la justicia, vemos con preocupación que algunas autoridades también han restringido y hasta cierto punto, suspendido algunos derechos humanos, que de acuerdo con el artículo 29 constitucional, no pueden suspenderse ni restringirse bajo la declaratoria prevista en ese mismo precepto, y mucho menos, por acuerdos adoptados por esas autoridades.

Como ejemplo, podemos referir que el derecho a la protección judicial o el derecho de acceso a la justicia, se vio mermado con el acuerdo 3/2020, emitido por el máximo tribunal constitucional, del país de fecha 17 de marzo del 2020, mediante el cual se suspenden actividades jurisdiccionales y, por ende, se declaran inhábiles los días que comprenden del dieciocho de marzo al diecinueve de abril de dos mil veinte, y se habilitan los días que resulten necesarios para proveer sobre la admisión y suspensión de controversias constitucionales urgentes (SCJN 1, 2020).

Asimismo, siguiendo la dinámica del pleno de la SCJN, el pleno del Consejo de la Judicatura Federal (CJF), con fecha 17 de marzo del 2020, emitió el acuerdo general 4/2020, 
relativo a las medidas de contingencia en los órganos jurisdiccionales del Poder Judicial de la Federación por el fenómeno de salud pública derivado del virus COVID-19. En dicho acuerdo se determinó suspender las funciones jurisdiccionales en los órganos del Poder Judicial de la Federación del 18 de marzo al 19 de abril del 2020. Y como consecuencia de ello se determinó que no corrieran plazos y términos procesales, ni se celebraran audiencias y tampoco se llevaran a cabo sesiones de los Plenos de Circuito. Quedando exceptuados de la medida anterior, los órganos jurisdiccionales que se encuentren de guardia, exclusivamente para la atención de asuntos urgentes, entendiéndose por éstos, los comprendidos en los artículos 15 de la Ley de Amparo y 48, fracciones I, III a IX, XI y XII ${ }^{2}$ del Acuerdo General del Pleno del Consejo de la Judicatura Federal, que establece las disposiciones en materia de actividad administrativa de los órganos jurisdiccionales (CJF 1, 2020).

Determinación que desde nuestro particular punto de vista, fue indebidamente ampliada hasta el día 5 de mayo del 2020, en función del acuerdo de la Secretaría de Salud de fecha 31 de marzo del 2020, a través del acuerdo general 6/2020 del pleno del CJF, por el que reforma y adiciona el similar 4/2020, relativo a las medidas de contingencia en los órganos jurisdiccionales por el fenómeno de salud pública derivado del virus COVID-19. No obstante, se califica como positivo la ampliación del número de casos que debían de considerarse urgentes, tomando en consideración los derechos humanos en juego, la trascendencia de su eventual trasgresión y las consecuencias que pudiera traer la espera a la conclusión del periodo de contingencia (CJF 2, 2020).

También la SCJN amplió la suspensión de actividades hasta el 5 de mayo del 2020 en posterior acuerdo emitido por el pleno el día 13 de abril del 2020 (SCJN 2, 2020), pero con la novedad de que en tal acuerdo al menos ya se contienen los lineamientos para que se celebren sesiones a distancia del pleno y las salas de ese alto tribunal en los casos urgentes.

Posterior a la emisión del acuerdo de abril que antecede, la SCJN mediante el acuerdo 7/2020 amplió de nuevo la suspensión de actividades jurisdiccionales del 6 de mayo al 31 de mayo, habilitando los días necesarios para la práctica de actuaciones judiciales precisadas en el acuerdo (SCJN 3, 2020).

\footnotetext{
2 El artículo 48 de la Ley de Amparo en las fracciones señaladas entre otros supuestos señala: ejercicio de la acción penal con detenido; diligenciación de exhortos en que deba resolverse sobre la situación jurídica; solicitudes de orden de cateo; solicitudes de intervención de comunicaciones privadas; solicitudes de extradición; orden de expulsión del país; orden de arraigo; demandas de amparo contra actos que importen peligro de privación de la vida, ataques a la libertad personal fuera de procedimiento judicial, incomunicación, deportación o expulsión, destierro, extradición, desaparición forzada de personas, malos tratos, tortura psicológica, segregación y demás prohibidos por el artículo 22 de la constitución; así como, las presentadas por falta de atención médica especializada de las personas privadas de su libertad en un centro de reclusión.
} 
Asimismo, mediante el Acuerdo General 10/2020, la SCJN declaró inhábiles los días del 1 al 30 de junio del 2020 y se habilitaron los días necesarios para la práctica de actuaciones judiciales que se precisan en el acuerdo (SCJN 4, 2020).

Por su parte, el pleno del CJF después tomar conciencia sobre la naturaleza esencial de las actividades de impartición de justicia, mediante el acuerdo 8/2020, fijó las bases de un nuevo esquema de trabajo y dictó las medidas de contingencia en los órganos jurisdiccionales, por el fenómeno de salud pública derivado del COVID-19, que estarían vigentes del 6 al 31 de mayo del 2020 (CJF 3, 2020).

De dicho acuerdo se destaca que únicamente se daría trámite a los casos nuevos que se califiquen como urgentes, ya sea que fueran promovidos de forma física o mediante juicio en línea, en atención al capítulo 1 de tal acuerdo, mediante el cual se ampliaron los supuestos para ese tipo de casos, de forma enunciativa y no limitativa (CJF 3, 2020).

Igualmente, se ordenó la reanudación de la resolución de casos ya radicados y que se hayan tramitado físicamente, en los que sólo quede pendiente la emisión de la sentencia, en conformidad con lo establecido en el capítulo II del referido acuerdo (CJF 3, 2020).

De igual manera, se acordó reanudar el trámite y resolución de los asuntos que se hayan tramitado mediante juicio en línea con anterioridad al inicio del periodo de contingencia, con excepción de aquéllos en los cuales quedara pendiente la celebración de audiencias o el desahogo de diligencias judiciales que requirieran la presencia física de las partes o de la práctica de notificaciones personales, en atención al capítulo III del citado acuerdo (CJF 3, 2020).

Y finalmente, se acordó la suspensión de plazos y términos, y la no celebración de audiencias y práctica de diligencias, cuando se tratara de solicitudes, demandas, recursos, juicios y procedimientos en general, distintos a los anteriores, así como para la interposición de los recursos en contra de las sentencias y resoluciones dictadas en los casos tramitados físicamente (CJF 3, 2020).

Como se puede apreciar de dicho acuerdo, a pesar del esfuerzo del CJF por ampliar el derecho de acceso a la justicia en casos de contingencia, éste continuó restringido solo a los casos urgentes, a la resolución de expedientes tramitados físicamente (cuando solo faltara la sentencia), y el trámite y resolución de los juicios en línea (siempre y cuando no quedaran pendiente la celebración de audiencias o el desahogo de diligencias donde se requiera la presencia física de las partes o de la práctica de notificaciones personales). Quedando exceptuados todos los demás casos. 
Posteriormente el CJF mediante acuerdo 10/2020 de fecha 25 de mayo del 2020, amplió el periodo de las medidas tomadas en el acuerdo 8/2020, del 6 al 15 de junio del 2020 (CJF 4, 2020). Por lo que se mantuvieron en esencia las medidas de acceso a la justicia de las que se dieron cuenta.

Como se puede apreciar, si bien no se paralizó por completo la actividad jurisdiccional en los órganos del poder judicial de la federación, el derecho de acceso a la justicia se vio significativamente limitado prácticamente desde el inicio de la pandemia en México, ello, no obstante que en conformidad con el acuerdo de la Secretaría de Salud de fecha 31 de marzo del 2020, la administración de justicia fue considerada una actividad esencial, y por ende, no podía haber sido restringida ni suspendida bajo ningún motivo.

Incluso, dichas determinaciones de los plenos de la SCJN y del CJF, fueron seguidas por la gran mayoría de tribunales del país -un ejemplo de ello lo tenemos en el Estado de Durango, el cual también suspendió actividades de manera paralela a los órganos del Poder Judicial de la Federación- (Tribunal Superior de Justicia del Estado de Durango 1, 2, 3, 2020), lo que conlleva básicamente a una interferencia grave al derecho de acceso a la justicia, el que de acuerdo con el artículo 29 constitucional, no puede ser restringido ni suspendido ni bajo el procedimiento excepcional que prevé el precepto constitucional en cita.

La postura de los tribunales del país de restringir el acceso a la justicia con la suspensión de actividades jurisdiccionales, también resulta reprochable desde el derecho internacional de los derechos humanos, y aquí cabe destacar que la Comisión Interamericana de Derechos Humanos, en la resolución I/2020, relacionada con el tema Pandemia y Derechos Humanos en las Américas, adoptada el 10 de abril del $2020^{3}$, dispuso en los puntos resolutivos del 23 al 26, relacionados con los Estados de excepción, restricciones a las libertades fundamentales y Estado de Derecho que, los estados deben de abstenerse de suspender el derecho al reconocimiento de la personalidad jurídica; el derecho a la vida; el derecho a la integridad personal y la prohibición de tortura, tratos inhumanos, crueles y degradantes; la prohibición de esclavitud y servidumbre; el principio de legalidad y retroactividad; la libertad de conciencia y religión; la protección a la familia; el derecho al nombre; los derechos de la niñez; el derecho a la nacionalidad, y los derechos políticos -lo cual es acorde a lo preceptuado por el artículo 29 constitucional- (CIDH, 2020).

\footnotetext{
${ }^{3}$ Disponible en http://oas.org/es/cidh/decisiones/pdf/Resolucion-1-20-es.pdf, consultada el 13 de abril del 2020.
} 
Asimismo, dispuso que los Estados deben de abstenerse de suspender procedimientos judiciales idóneos para garantizar la plenitud del ejercicio de los derechos y libertades, entre ellos las acciones de hábeas corpus y amparo para controlar las actuaciones de las autoridades, incluyendo las restricciones a la libertad personal en dicho contexto. Debiendo dichas garantías ejercitarse bajo el marco y principios del debido proceso legal (CIDH, 2020).

De igual modo, resolvió que los Estados deben de abstenerse de suspender aquellas garantías judiciales indispensables, como el recurso de amparo y hábeas corpus, que son idóneas para garantizar la plenitud del ejercicio de los derechos y libertades, y para controlar las actuaciones de las autoridades en el contexto de los estados de excepción (CIDH, 2020).

De igual manera, resolvió que se debe asegurar que la proclamación de un estado de excepción sea realizada de conformidad con el marco constitucional y demás disposiciones que rijan tal actuación, y que se identifiquen expresamente los derechos cuyo pleno goce será limitado, así como el ámbito temporal y geográfico que justifica tal excepción (CIDH, 2020).

En ese orden de ideas, cabe mencionar que en la Declaración "Emergencia del coronavirus: desafíos para la justicia”, el Relator Especial de Naciones Unidas sobre independencia judicial: estimó urgente la racionalización inmediata de los servicios que prestan los sistemas de justicia en torno a asuntos que pueden considerarse prioritarios, y apuntó que debe ser puesto en funcionamiento de manera urgente, el uso de las tecnologías informáticas y el teletrabajo para enfrentar la crisis actual (Organización de las Naciones Unidas, 2020).

Tales parámetros convencionales que resultan vinculantes para el Estado Mexicano en términos del artículo $1^{\circ}$ de la Constitución Federal, no fueron respetados por los tribunales del país, incluyendo la SCJN, pues dispusieron de facto la suspensión del derecho de acceso a la justicia prácticamente para muchos supuestos, quedando limitado el acceso a la protección judicial a los supuestos que la ley considera urgentes, aunque con posterioridad fueron ampliados mediante los acuerdos generales de los que se dio cuenta.

Y lo anterior no es una cuestión de menor importancia, dado que la comisión interamericana y nuestra propia carta magna en el artículo 29 señalan que el derecho acceso a la justicia no puede restringirse ni suspenderse bajo ningún contexto, vaya, ni siquiera en un estado de excepción pueden limitarse las garantías judiciales necesarias para proteger los Derechos Humanos.

Consecuentemente, nos parece reprochable la conducta de nuestro máximo tribunal constitucional, del pleno del CJF y de la gran mayoría de los tribunales del país, que so pretexto de la emergencia sanitaria originada por el COVID-19, restringieron por un buen tiempo el acceso a la justicia. 
¿Pero qué hacer en estos casos para que se active la función jurisdiccional en tiempos de emergencia sanitaria?

El uso de las nuevas tecnologías y el teletrabajo ya no deben de ser una opción a la hora de garantizar el acceso a la justicia. Ya lo apuntaba el Relator Especial de las Naciones Unidas sobre Independencia Judicial: se debe de implementar de manera urgente el uso de las nuevas tecnologías y el teletrabajo para atender a los justiciables. "Las cuarentenas y las "distancias sociales" no deben impedir que el sistema judicial funcione y que lo haga respetando el debido proceso. La situación actual plantea la exigencia de "ponerse al día" y de hacerlo ya con el teletrabajo" (Organización de las Naciones Unidas, 2020).

Por lo que en el contexto de la contingencia sanitaria COVID-19, los tribunales del país deben de apostarle al uso de las nuevas tecnologías y al teletrabajo para garantizar el acceso a la justicia de las personas.

Y esto finalmente fue comprendido por el pleno de la SCJN, aunque un poco tarde, con la emisión del Acuerdo General número 8/2020, de fecha 21 de mayo del 2020, por el que se regula la integración de los expedientes impreso y electrónico en controversias constitucionales y en acciones de inconstitucionalidad, así como el uso del sistema electrónico de este alto tribunal para la promoción, trámite, consulta, resolución y notificaciones por vía electrónica en los expedientes respectivos (SCJN 5, 2020).

También con la emisión del Acuerdo General número 9/2020, de fecha 26 de mayo del 2020, por el que se regula la integración de los expedientes impreso y electrónico en los asuntos de la competencia de este Alto Tribunal, salvo en controversias constitucionales y en acciones de inconstitucionalidad, así como el uso del sistema electrónico de la SCJN para la promoción, trámite, consulta, resolución y notificaciones por vía electrónica en los expedientes respectivos (SCJN 6, 2020).

En tales acuerdos generales se prevé ya el uso de las nuevas tecnologías para atender los asuntos de competencia de la SCJN.

Asimismo, ya en una etapa avanzada de la emergencia sanitaria, con fecha 8 de junio del 2020, el CJF emitió el Acuerdo General 12/2020, que regula la integración y trámite de expediente electrónico y el uso de videoconferencias en todos los asuntos competencia de los órganos jurisdiccionales a cargo del propio consejo (CJF 5, 2020).

El acuerdo anterior fue complementado con el diverso Acuerdo General 13/2020, de fecha de junio 8 de junio del 2020, relativo al esquema de trabajo y medidas de contingencia en los órganos jurisdiccionales por el fenómeno de salud pública derivado del virus COVID-19 (CJF 6, 2020). 
De este último acuerdo, se destacan los siguientes aspectos:

a) Bajo ese nuevo esquema de trabajo, se prescribió la reanudación de las actividades judiciales en mayor escala (pero no en su totalidad), aplicable del 16 al 30 de junio del 2020 (CJF 6, 2020);

b) Respecto de la tramitación de casos urgentes presentados físicamente, se dispuso que desde la primera actuación, las y los juzgadores, incluyendo a secretarias y secretarios en funciones o encargados de exhortarán a las partes a que, de ser posible y tomando en consideración las potenciales dificultades para acceder a las herramientas tecnológicas necesarias para ello, continúen la tramitación del caso mediante el juicio en línea, utilizando los medios electrónicos disponibles desde el portal de servicios en línea del poder judicial de la federación (CJF 6, 2020);

c) Por lo que hace a la resolución de casos tramitados físicamente, se habilitó la posibilidad de resolver aquellos casos ya radicados y que se hayan tramitado físicamente, en los que únicamente quede pendiente la emisión de sentencia o resolución final, de conformidad con lo previsto en el capítulo II del citado Acuerdo (CJF 6, 2020);

d) Se habilitó la recepción de casos nuevos, la reanudación de los radicados con anterioridad al inicio del período de contingencia y, en ambos casos, su tramitación y eventual resolución, siempre que la totalidad o la mayoría de sus actuaciones se puedan realizar a través de medios electrónicos, mediante el esquema conocido como juicio en línea; con excepción de los casos en los cuales se requiera la celebración de audiencias o el desahogo de diligencias judiciales en las que se requiera la presencia física de las partes y que no puedan desahogarse mediante videoconferencias, o cuando resulte necesaria la práctica de notificaciones personales, de conformidad con lo dispuesto en el capítulo III del citado acuerdo (CJF 6, 2020), y

e) Se acordó la suspensión de plazos y términos, y la no celebración de audiencias y práctica de diligencias, cuando se tratara de solicitudes, demandas, recursos, juicios y procedimientos en general, distintos a los anteriores, así como para la interposición de los recursos en contra de las sentencias y resoluciones dictadas en los casos tramitados físicamente.

Como se puede apreciar del acuerdo en cuestión, el derecho de acceso a la justicia fue ampliado de forma considerable, pero no en su totalidad, ya que quedaron fuera aquellos casos en los que se requiriera necesariamente la presencia física de las partes, o cuando resultara necesario la práctica de notificaciones personales. No obstante, se aprecia que a través del uso de las nuevas tecnologías se puede potenciar significativamente el derecho de acceso a la justicia, por lo que hoy día, la pandemia COVID-19 no puede ser utilizada como pretexto para que se encuentre paralizada la justicia en la mayor parte del país. 
Con todo, se considera que el Poder Judicial de la Federación pudiera garantizar plenamente el derecho de acceso a la justicia, si además del uso de las nuevas tecnologías y el teletrabajo, tramitara, sustanciara y resolviera los casos donde se requiera la presencia física de las personas o el contacto personal, a través de las medidas sanitarias pertinentes y adecuadas para cada caso.

Se sostiene lo anterior, porque no existe una limitación que no se pueda superar sin las medidas sanitarias correspondientes, para llevar a cabo dicha actividad esencial, tal y como la están llevando a cabo los centros comerciales, mercados, bancos, transporte público, hospitales, etcétera. Y se recuerda que conforme al criterio sostenido por la CORTIDH en el caso Cantos Vs Argentina, cualquier norma o medida de carácter interno de los Estados que imponga costos o dificulte de cualquier otra manera el acceso de las personas a los tribunales, y que no se encuentren justificadas por las razonables necesidades de la administración de justicia, debe considerarse contraria a la Convención (CORTIDH, 2002, párrafo 50).

Consecuentemente, se concluye que el hecho de tener que llevar algún caso con la presencia física de las partes no debe considerarse una limitante para poder garantizar plenamente el derecho de acceso a la justicia, pues tales casos, se insiste, se pueden llevar a cabo tomando las medidas sanitarias correspondientes, tal y como la están llevando otras actividades consideradas como esenciales.

De ahí que se estime que todos los tribunales del país, si hacen un uso adecuado de las nuevas tecnologías, teletrabajo y celebración de casos con la presencia física de las partes, pueden garantizar plenamente el derecho de acceso a la justicia, a pesar de la contingencia sanitaria generada por el COVID-19.

\section{FUENTES DE LA INVESTIGACIÓN}

Alexy, Robert. (1997). Teoría de los derechos fundamentales, Ed. Centro de Estudios Políticos y Constitucionales, Madrid.

Cámara de Diputados del Congreso de la Unión 1. (2020). Constitución Política de los Estados Unidos Mexicanos. Disponible en http://www.diputados.gob.mx/LeyesBiblio/pdf_mov/Constitucion_Politica.pdf, [consultada el 12 de mayo del 2020].

Cámara de Diputados del Congreso de la Unión 2. (2020). Ley General de Salud. Disponible en http://www.diputados.gob.mx/LeyesBiblio/pdf/142_240120.pdf, [consultada el 12 de mayo del 2020]. 
Centro para el Control y la Prevención de Enfermedades. (2020). Disponible en https://espanol.cdc.gov/flu/pandemic-resources/2009-h1n1-pandemic.html, [consultada el 9 de septiembre del 2020].

CJF 1. (2020). Acuerdo General 4/2020, del Pleno del Consejo de la Judicatura Federal, relativo a las medidas de contingencia en los órganos jurisdiccionales por el fenómeno de salud pública derivado del virus COVID-19, publicado en el DOF de fecha 18 de marzo de 2020, disponible en http://www.dof.gob.mx/nota_detalle.php?codigo $=5589993 \&$ fecha $=20 / 03 / 2020$, [consultada el 8 de abril del 2020].

CJF 2. (2020). Acuerdo general 6/2020 del pleno del CJF, por el que reforma y adiciona el similar 4/2020, relativo a las medidas de contingencia en los órganos jurisdiccionales por el fenómeno de salud pública derivado del virus COVID-19. Disponible en https://www.cjf.gob.mx/resources/index/infoRelevante/2020/pdf/AcuerdoGeneral6_2020.pdf, [consultada el 13 de abril de 2020].

CJF 3. (2020). Acuerdo General 8/2020, del pleno del Consejo de la Judicatura Federal, relativo al esquema de trabajo y medidas de contingencia en los órganos jurisdiccionales por el fenómeno de salud pública derivado del virus covid19. Disponible en https://www.cjf.gob.mx/resources/index/infoRelevante/2020/pdf/AcuerdoGeneral8_2020.pdf, [consultada el 9 de junio del 2020].

CJF 4. (2020). Acuerdo General 10/202, del pleno del Consejo de la Judicatura Federal, que reforma el similar 8/2020, relativo al esquema de trabajo y medidas de contingencia en los órganos jurisdiccionales por el fenómeno de salud pública derivado del virus covid-19, en relación con el periodo de vigencia. Disponible en https://www.cjf.gob.mx/resources/index/infoRelevante/2020/pdf/AcuerdoGeneral10_2020.pd f, [consultada el 9 de junio del 2020].

CJF 5. (2020). Acuerdo General 12/2020, del pleno del Consejo de la Judicatura Federal, que regula la integración y trámite de expediente electrónico y el uso de videoconferencias en todos los asuntos competencia de los órganos jurisdiccionales a cargo del propio consejo. Disponible en https://www.cjf.gob.mx/resources/index/infoRelevante/2020/pdf/AcuerdoGeneral12_2020.pd f, [consultada el 10 de junio del 2020].

CJF 6. (2020). Acuerdo General 13/2020, del pleno del Consejo de la Judicatura Federal, relativo al esquema de trabajo y medidas de contingencia en los órganos jurisdiccionales por el fenómeno de salud pública derivado del virus covid-19. Disponible en https://www.cjf.gob.mx/resources/index/infoRelevante/2020/pdf/AcuerdoGeneral13_2020.pd f, [consultada el 10 de junio del 2020].

CORTIDH. (2002). Caso Cantos Vs. Argentina. Sentencia de 28 de noviembre de 2002 (Fondo, Reparaciones y Costas). Disponible en https://www.corteidh.or.cr/docs/casos/articulos/seriec_97_esp.pdf, [consultada el 2 de junio del 2020].

CORTIDH. (2003). Caso Maritza Urrutia Vs. Guatemala. Sentencia de 27 de noviembre de 2003 (Fondo, Reparaciones y Costas). Disponible en 
https://www.corteidh.or.cr/docs/casos/articulos/seriec_103_esp.pdf, [consultada el 2 de junio de 2020].

CORTIDH. (2006). Caso López Álvarez Vs. Honduras. Sentencia de 1 de febrero de 2006 (Fondo, Reparaciones y Costas). Disponible en

https://www.corteidh.or.cr/docs/casos/articulos/seriec_141_esp.pdf, [consultada el 2 de junio del 2020].

CORTIDH. (2008). Caso Castañeda Gutman Vs. Estados Unidos Mexicanos. Sentencia de 6 de agosto de 2008 (Excepciones Preliminares, Fondo, Reparaciones Y Costas). Disponible en http://www.corteidh.or.cr/docs/casos/articulos/seriec_184_esp.pdf, [consultada el 2 de junio del 2020].

CSG 1. (2020). Acuerdo del CSG por el que se reconoce la epidemia de enfermedad por el virus SARS-CoV2 (COVID-19) en México, como una enfermedad grave de atención prioritaria, así como se establecen las actividades de preparación y respuesta ante dicha epidemia. Publicado en el Diario Oficial de la Federación (DOF) con fecha 23 de marzo de 2020, disponible en

https://www.dof.gob.mx/nota_detalle.php?codigo $=5590161 \&$ fecha $=23 / 03 / 2020$, [consultada el 1 de abril de 2020].

CSG 2. (2020). Acuerdo del CSG por el que se declara como emergencia sanitaria por causa de fuerza mayor, a la epidemia de enfermedad generada por el virus SARS-CoV2 (COVID19). Publicado en el DOF el 30 de marzo del 2020, disponible en http://dof.gob.mx/2020/CSG/CSG_300320_VES.pdf, [consultada el 1 de abril de 2020].

Consejo de Salubridad General. (2009). Reglamento Interior del Consejo de Salubridad General. Disponible en http://www.csg.gob.mx/descargas/pdf/normatividad/Reglamento_Interior_del_CSG-2013.pdf, [consultada el 12 de mayo del 2020].

Gobierno del Estado de Sonora. (2020). Decreto de estado de emergencia publicado en el Boletín Oficial del Gobierno del Estado de Sonora de fecha 25 de marzo de 2020, disponible en https://www.sonora.gob.mx/images/documentos/boletin_oficial_EE25032020.pdf, [consultada el 1 de abril de 2020].

Gobierno de España. (2020). Real Decreto de Estado de Alarma emitido por el Gobierno de España de fecha 14 de marzo de 2020. Disponible en https://www.boe.es/eli/es/rd/2020/03/14/463, [consultada el 30 de marzo del 2020].

Islas Colín, Alfredo y Díaz Alvarado, Alejandra. (2016). "El Derecho al acceso a la Justicia en el Sistema Interamericano de Protección de Derechos Humanos: construcción doctrinal y jurisprudencial”. Prospectiva Jurídica, UAEM, año 7, número 14, julio-diciembre. pp. 47-60.

Organización Mundial de la Salud. (2020). Alocución de apertura del Director General de la OMS en la rueda de prensa sobre la COVID-19 celebrada el 11 de marzo de 2020, disponible en https://www.who.int/es/dg/speeches/detail/who-director-general-s-opening-remarks-at-themedia-briefing-on-covid-19---11-march-2020, [consultada el 30 de marzo de 2020]. 
Organización de las Naciones Unidas. (2020). Declaración del Relator Especial de Naciones Unidas sobre independencia judicial, Diego García-Sayán. Emergencia del coronavirus: desafíos para la justicia. Disponible en https://www.ohchr.org/SP/NewsEvents/Pages/DisplayNews.aspx?NewsID=25810\&LangID=

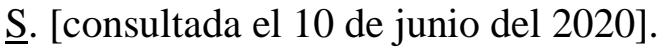

Pérez Vázquez, Carlos. (2020). Acceso a la Justicia. México. Enciclopedia Jurídica Online. Disponible en https://mexico.leyderecho.org/acceso-a-la-justicia/, [consultada el 1 de junio del 2020].

Reynoso, Carlos Alonso. (2010). "La influenza A (H1N1) y las medidas adoptadas por las autoridades sanitarias”, en Desacatos, número 32, enero-abril.

Real Academia Española. 2020. Diccionario Español Jurídico. Voz. Acceso a la justicia. Disponible en https://dej.rae.es/lema/acceso-a-la-justicia, [consultada el 1 de junio del 2020].

Redacción Médica. (2020). "Coronavirus, origen y evolución y por qué no es igual que el SARS y el MERS. Disponible en https://www.redaccionmedica.com/secciones/sanidadhoy/coronavirus-origen-evolucion-por-que-no-es-igual-sars-mers-1429, [consultada el 30 de marzo de 2020].

Secretaría de Salud 1. (2020). Acuerdo de la Secretaría de Salud de fecha 24 de marzo de 2020, por el que se establecen las medidas preventivas que se deberán implementar para la mitigación y control de los riesgos para la salud que implica la enfermedad por el virus SARSCoV2 (COVID-19), publicado en el DOF con fecha 24 de marzo del 2020, disponible en https://www.dof.gob.mx/nota_detalle.php?codigo=5590339\&fecha=24/03/2020, [consultada el 30 de marzo del 2020].

Secretaría de Salud 2. (2020). Acuerdo de la Secretaría de Salud por el que se establecen acciones extraordinarias para atender la emergencia sanitaria generada por el virus SARSCoV2 COVID-19, publicado en el DOF con fecha 31 de marzo del 2020, disponible en https://www.dof.gob.mx/nota_detalle.php?codigo=5590914\&fecha=31/03/2020\&print=true, [consultada el 1 de abril del 2020].

Secretaría de Salud 3. (2020). Acuerdo de la Secretaría de Salud por el que se establecen los lineamientos técnicos relacionados con las actividades descritas en los incisos c) y e) de la fracción II del Acuerdo por el que se establecen acciones extraordinarias para atender la emergencia sanitaria generada por el virus SARS-Co V2, publicado el 31 de marzo del 2020, disponible en http://dof.gob.mx/nota detalle.php?codigo=5591234\&fecha=06/04/2020, [consultada el 7 abril del 2020].

SCJN. (2017). Tesis $1^{\mathrm{a}}$./J. 103/2017, DERECHO DE ACCESO EFECTIVO A LA JUSTICIA. ETAPAS Y DERECHOS QUE LE CORRESPONDEN. Gaceta del Semanario Judicial de la Federación, Libro 48, noviembre 2017, Tomo 1.

SCJN 1. (2020). Acuerdo General número 3/2020, de diecisiete de marzo de dos mil veinte, del Pleno de la Suprema Corte de Justicia de la Nación, por el que se suspenden actividades jurisdiccionales y, por ende, se declaran inhábiles los días que comprenden del dieciocho de marzo al diecinueve de abril de dos mil veinte, y se habilitan los días que resulten necesarios para proveer sobre la admisión y suspensión de controversias constitucionales urgentes, 
publicado en el DOF de fecha 18 de marzo de 2020, disponible en https://www.dof.gob.mx/nota_detalle.php?codigo $=5589708 \&$ fecha $=18 / 03 / 2020$, [consultada el 8 de abril de 2020].

SCJN 2. (2020). Acuerdo General número 6/2020, de trece de abril de dos mil veinte, del Pleno de la Suprema Corte de Justicia de la Nación, por el que se prorroga la suspensión de actividades jurisdiccionales y, por ende, se declaran inhábiles los días del periodo comprendido del veinte de abril al cinco de mayo de dos mil veinte, y se habilitan los días que resulten necesarios para proveer sobre la admisión y suspensión de controversias constitucionales urgentes, así como para la celebración a distancia de las sesiones sel Pleno y de las Salas de ese Tribunal. Disponible en https://www.scjn.gob.mx/sites/default/files/acuerdos_generales/documento/2020-04/62020\%20\%28PR\%C3\%93RROGA\%20SUSP.\%20ACT.\%20JURISD.\%29\%20FIRMA.pdf, [consultada el 15 de abril del 2020].

SCJN 3. (2020). Acuerdo General número 7/2020, de veintisiete de abril de dos mil veinte, del pleno de la Suprema Corte de Justicia de la Nación, por el que se prorroga la suspensión de actividades jurisdiccionales y, por ende, se declaran inhábiles los días del periodo comprendido del seis al treinta y uno de mayo de dos mil veinte, y se habilitan los días que resulten necesarios para las actuaciones jurisdiccionales que se precisan. Disponible en https://www.scjn.gob.mx/sites/default/files/acuerdos_generales/documento/2020-04/72020\%20\%28PR\%C3\%93RROGA\%20SUSP.\%20ACT.\%20JURISD.\%20AL\%2031\%20MA YO\%202020\%29\%20FIRMA.pdf, [consultada el 30 de abril del 2020].

SCJN 4. (2020). Acuerdo General número 10/2020, de veintiséis de mayo de dos mil veinte, del pleno de la Suprema Corte de Justicia de la Nación, por el que se declaran inhábiles los días del periodo comprendido del uno al treinta de junio de dos mil veinte, $\mathrm{y}$ se habilitan los días que resulten necesarios para las actuaciones jurisdiccionales que se precisan. Disponible en https://www.scjn.gob.mx/sites/default/files/acuerdos_generales/documento/2020-05/102020\%20\%28PR\%C3\%93RROGA\%20SUSP.\%20ACT.\%20JURISD.\%20AL\%2030\%20JU NIO\%202020\%29\%20FIRMA.pdf, [consultada el 1 de junio del 2020].

SCJN 5. (2020). Acuerdo General número 8/2020, del pleno de la Suprema Corte de Justicia de la Nación, por el que se regula la integración de los expedientes impreso y electrónico en controversias constitucionales y en acciones de inconstitucionalidad, así como el uso del sistema electrónico de este alto tribunal para la promoción, trámite, consulta, resolución y notificaciones por vía electrónica en los expedientes respectivos. Disponible en https://www.scjn.gob.mx/sites/default/files/acuerdos_generales/documento/2020-05/82020\%20\%28EXP.\%20IMPRESO\%20Y\%20ELECTR\%C3\%93NICO\%20EN\%20CC\%20Y \%20AI\%20Y\%20NOTIFICACIONES\%29\%20FIRMA.pdf, [consultada el 10 de junio del 2020].

SCJN 6. (2020). Acuerdo General número 9/2020 del Pleno de la Suprema Corte de Justicia de la Nación, por el que se regula la integración de los expedientes impreso y electrónico en los asuntos de la competencia de este Alto Tribunal, salvo en controversias constitucionales y en acciones de inconstitucionalidad, así como el uso del sistema electrónico de la Suprema Corte de Justicia de la Nación para la promoción, trámite, consulta, resolución y notificaciones por vía electrónica en los expedientes respectivos. Disponible en https://www.scjn.gob.mx/sites/default/files/acuerdos_generales/documento/2020-05/92020\%20\%28TRAMITACI\%C3\%93N\%20ELEC.\%20ASUNTOS\%20COMP.\%20SCJN\%2 
Quaestio Iuris

vol. 14, no. 01, Rio de Janeiro, 2021. pp. 122-154 DOI: $10.12957 /$ rqi.2021.55062

C\%20SALVO\%20CC\%20Y\%20AI\%29\%20FIRMA.pdf, [consultada el 10 de junio del 2020].

Trabalho recebido em 05 de outubro de 2020

Aceito em 03 de dezembro de 2020 